\title{
“İsrail'de Yahudi Fundamentalizmi” kitabı ekseninde, İsrail iç siyasetine dair bazı yapısal ve aktüel gözlemler
}

Mehmet Akif KOÇ

Received: May 28, $2021 \quad$ Reviewed: August 2, $2021 \quad$ Accepted: August 15, 2021

\section{$\ddot{\mathbf{O} z}$}

Türkiye de dâhil olmak üzere, uluslararası kamuoyu, İsrail Devleti'nin komşularına karşı 'meşru müdafaa' konseptini aşan davranışlarına son dönemde sıkça şahit oldu. İsrail'in insan haklarını da açıkça ihlal eden bu tür adımlarının uluslararası sahnedeki yansımaları ve olası sonuçları her platformda sıklıkla tartışıldı. Ancak, ülke içinde bu saldırganlığı besleyen dini ve toplumsal iklim, pek dikkati çekmedi. İsrail'in güvenlik politikaları ve dış ilişkileri üzerinde de oldukça etkili olan bu iç dinamikler, yakından incelenmeyi hak edecek kadar ciddi ve etkili bir çerçeveye sahiptir. Son dönemde "Shtisel" ve "Unorthodox" gibi iki önemli diziyle, Türk kamuoyunun da gündemine giren İsrail'deki radikal/dindar Yahudiler hakkında; iki Yahudi yazar, Israel Shahak ve Norton Mezvinsky'nin kaleme aldıkları, İsrail'de Yahudi Fundamentalizmi, bu noktada önemli bir siyasi, kültürel ve toplumsal arka plan sunmaktadır. Bu yazının ilk bölümünde, Shahak / Mezvinsky'nin bahsekonu kitabından hareketle, İsrail toplumunda köktenci Yahudilerin konumu ele alınacak; ikinci kısımda ise -2021 Mart ayında yapılan son Knesset seçimleri ekseninde- kitapta değinilen radikal Yahudi toplumunun İsrail iç siyasetindeki konumu örneklenecektir. Bu yönüyle "kitap incelemesi” formatının bir miktar ötesine geçilip, 1999'da ilk olarak yayınlanan bu kitabın son dönemdeki verilerle örneklendirilip bir anlamda güncel bir değerlendirmesi sunulmaya gayret edilecektir.

Anahtar Kelimeler: İsrail, fundamentalizm, din, hak, güvenlik

\section{Recommended citation:}

Koç, M.A. (2021). "İsrail'de Yahudi Fundamentalizmi” kitabı ekseninde, İsrail iç siyasetine dair bazı yapısal ve aktüel gözlemler. International Journal of Kurdish Studies 7 (2), 308321, DOI: https://doi.org/10.21600/ijoks.944071

\footnotetext{
${ }^{1}$ Corresponding Author: Ph.D Can., Middle East Studies, Ankara / Turkey, E-mail: akifkoc@hotmail.com, ORCID ID: https://orcid.org/ 0000-0001- 5179-6027
} 


\title{
Some structural and contemporary observations on Israeli politics around the "Jewish
} Fundamentalism in Israel" volume of Shahak\&Mezvinsky

\begin{abstract}
Israel's aggressive foreign policy and use of excessive violence trigger profound concerns and draw reaction from regional countries and international community. Israel's sui generis domestic factors, created by socio-cultural and historically-religiously legitimized claims, closely affect its aggressiveness within the country and beyond. This article will follow a different perspective in analyzing this situation; first, Israeli domestic politics shaped by religious parameters will be discussed in detail around Jewish Fundamentalism in Israel, Israel Shahak and Norton Mezvinsky's well-known research. Then contemporary dynamics in Israeli politics creating a strong religious-right tendency will be evaluated while focusing on the last parliamentary elections (March 2021).
\end{abstract}

Keywords: Israel, fundamentalism, religious, right, security.

Türkiye de dâhil olmak üzere, uluslararası kamuoyu, İsrail Devleti'nin komşularına karşı 'meşru müdafaa' konseptini aşan davranışlarına son dönemde sıkça şahit oldu. İsrail'in insan haklarını da açıkça ihlal eden bu tür adımlarının uluslararası sahnedeki yansımaları ve olası sonuçları her platformda sıklıkla tartışıldı. Ancak, ülke içinde bu saldırganlığı besleyen dini ve toplumsal iklim, pek dikkati çekmedi. İsrail'in güvenlik politikaları ve dış ilişskileri üzerinde de oldukça etkili olan bu iç dinamikler, yakından incelenmeyi hak edecek kadar ciddi ve etkili bir çerçeveye sahiptir.

Son dönemde "Shtisel" ve "Unorthodox" gibi iki önemli diziyle, Türk kamuoyunun da gündemine giren İsrail'deki radikal/dindar Yahudiler hakkında; iki Yahudi yazar, Israel Shahak ve Norton Mezvinsky'nin kaleme aldıkları, İsrail'de Yahudi Fundamentalizmi, bu noktada önemli bir siyasi, kültürel ve toplumsal arka plan sunmaktadır. 
Bu yazının ilk bölümünde, Shahak / Mezvinsky’nin bahsekonu kitabından hareketle, İsrail toplumunda köktenci Yahudilerin konumu ele alınacak; ikinci kısımda ise -2021 Mart ayında yapılan son Knesset seçimleri ekseninde- kitapta değinilen radikal Yahudi toplumunun İsrail iç siyasetindeki konumu örneklenecektir. Bu yönüyle "kitap incelemesi" formatının bir miktar ötesine geçilip, 1999 'da ilk olarak yayınlanan bu kitabın son dönemdeki verilerle örneklendirilip bir anlamda güncel bir değerlendirmesi sunulmaya gayret edilecektir.

\section{a). Israel Shahak ve Norton Mezvinsky, Israil'de Yahudi Fundamentalizmi, trc. Ahmet Emin Dă̆, (İstanbul: Anka Yayınları, 2002).}

Kitabın ana yazarı Prof. Dr. Israel Shahak, 1933 yılında Polonya Yahudisi olarak dünyaya geldi. Almanların Polonya'yı işgali sonucu, ailesiyle birlikte önce Varşova'nın gettolarında yaşamaya mahkûm edildi, ardından toplama kamplarına gönderildi. Holokost'tan kurtulan şanslı Yahudiler arasında yer alan Shahak ailesi, savaşın ardından Filistin topraklarındaki Yahudi yerleşimlerine yerleşti, 1948'te ilan edilen İsrail Devleti'nin vatandaşı oldu. Kudüs'teki Hebrew Üniversitesi'nde kimya doktorası yaptı, akabinde Stanford Üniversitesi'nde post-doktora çalışmaları yaptı, Hebrew Üniversitesi'nde öğretim üyeliğinde bulundu, 2001 y1lında hayatını kaybetti.

Shahak, kimya alanındaki çalışmalarının dışında, daha ziyade politik mücadelesi ve İsrail Devleti'ne getirdiği eleştirilerle tanındı. Batı Şeria ve Gazze'deki hukuksuz İsrail işgaline, yerleşimlere ve Filistinlilere yönelik sert muamelelere cesurca karşı çıktı. Yurtdışında yaşayan Yahudi diasporasına yönelik hazırladığı ve gazeteci, insan hakları aktivistleri ve politikacılara gönderdiği İngilizce raporlarla (İsrail'de İşkence, Batı Şeria'da Toplu Cezalandırma vb konular üzerine), İsrail'deki muhafazakâr çevrelerin ve devletin tepkisini çekti. İnsan hakları savunucusu ve liberal bir entelektüel olarak şöhret kazanan Shahak, Yahudilik dini ve tarihi, İsrail dış politikası ve nükleer faaliyetleri üzerine sert ve eleștirel eserler kaleme aldı. Çalışmalarından bazıları şunlardır:

- The Non-Jew in the Jewish State; a collection of Documents, Jerusalem, 1975.

-(Noam Chomsky ile birlikte) Israel's Global Role: Weapons for Repression (Studies in

Geophysical Optics and Remote Sensing), Association of Arab-American University Graduates, Inc., 1982 
-The Zionist Plan for the Middle East, Association of Arab-American University Graduates, Inc., 1982

-Jewish History, Jewish Religion: The Weight of Three Thousand Years: Pluto Press, London, 1994

-Open Secrets: Israeli Foreign and Nuclear Policies, Pluto Press, London, 1997

-(Norton Mezvinsky ile birlikte) Jewish Fundamentalism in Israel, Pluto Press, London, 1999 1932 doğumlu, ABD’li tarihçi Prof. Dr. Norton Mezvinsky ise Central Connecticut State Üniversitesi'nde öğretim üyesi olarak görev yaptı. Arap-İsrail çatışması, Siyonizm, Yahudilik tarihi, modern dünyada terörizm konularında yayınlanmış çok sayıda kitap, makale ve analizi bulunmaktadır. Aslen Yahudi kökenli olmakla birlikte, ABD kamuoyunda, anti-Siyonist ve İsrail karşıtı görüşleriyle tanınır. Shahak ile birlikte kaleme aldıkları, Jewish Fundamentalism in Israel kitabı, yayınlandığı dil olan İngilizcenin dışında dört dile daha çevrilerek yayınlandı.

İsrail'de Yahudi Fundamentalizmi kitabı, toplam yedi ayrı bölümden oluşuyor:

-Yahudi Toplumunda Yahudi Köktenciliği

-İsrail' de Haredim'in Yükselişi

-İki Haredi Grup: Sefaradlar ve Aşkenazlar

-Ulusal Dini Parti (NRP) ve Dindar Yahudi Yerleşimciler

-Köktenci Gush Emunim Grubunun Yapısı

-Baruch Goldstein Olayının Gerçek Anlamı

-Rabin Suikastının Dini Arka Planı

Kitabın Önsöz kısmında, “İsrail' deki Yahudi köktenciliğini bölgedeki barışın önünde başlıca engel olarak görmekten kendimizi alamıyoruz. Yahudi köktenciliğinin barışa ve kurbanlarına yaptı̆̆ kötülük karşısında da dehşete düşmekten kendimizi alamıyoruz” sözleriyle, kitabın yazılış gayesi ve yazarların temel duruşu ortaya konuluyor. Keza, Yahudi köktenciliğinin temel prensiplerinin, diğer dinlerde bulunan köktenci gruplarınkiyle tamamen aynı olduğu ve "geçmişte var olduğu farz edilen o 'saf ve 'dindar' toplumu yeniden ihya ve inşa etmek" idealinin toplumları nasıl yanlış yöne sevk ettiği kitabın önemli vurguları arasında. İsrail dış politikası ve Filistinlilere karşı muamelenin, Mesiyanik köktencilikten kaynaklandığ 1 tespiti de ayrıca üzerinde durulması gereken bir husus. İsrail demokrasisine dair şu tespit, bu saldırgan eğilimlerin sadece dış politikayla ilgili olmadığını ortaya koyuyor: "En azından Ortodoks ve milliyetçi biçimleriyle İsrail'de yaygın bulunan Yahudi dininin değerleri, demokratik değerlerle kesinlikle bağdaşmaz. Ne milliyetçilik ne güvenlik hakkındaki 
tutumlar, ne sosyal ve ekonomik değerler ve ne de etnik bağlar konusundaki değişebilir nicelikler, Ísrail Yahudilerinin demokrasi karşıtı tutumlarını dindarlık kadar etkilemiştir." Yazarlar; çeşitli çevrelerde Yahudi efsanelerine dair eleştirel görüşlere anti-Semitizm yaftasıyla tepki gösterilirken, Yahudilerin kendi ırklarının üstün olduğuna ve diğer milletlerin kendilerine hizmet etmek için yaratıldığına dair fanatikçe inançlarını doğrudan doğruya 'münafiklık' olarak görür. Ancak bunu yaparken, “Umuyoruz ki; bizim eleştirilerimiz, Orta Doğu'daki diğer insanları da, kendileri hakkındaki bilgilerini arttırma ve diğerlerine karşı davranışlarını düzeltmek için kendi geçmişlerini eleştirel bir gözle yeniden ele almaları konusunda cesaretlendirir" diyerek, bu münafıkça davranışın sadece Yahudi fanatiklere ait olmadığını herkese bir kez daha hatırlatır.

Giriş bölümünde üzerinde durulan dikkat çekici bir konu; günümüzde Yahudiliğe büyük oranda yön veren Mesihçi perspektifin, doğrudan Yahudi kutsal metinlerine değil, onun bir yorumu mahiyetindeki Kabala mistisizmine dayanması ve bunun da XVI-XVIII. yüzyıllar arasında Avrupa'da şekillenip, sonradan İsrail'e ithal edilmesi keyfiyeti.

"Yahudi Toplumunda Yahudi Köktenciliği" başlıklı Birinci Bölüm, başka ülkelerde, köktenciliğin sonuçlarından birçok insanın duyduğu benzer korkuların, İsrail'de bizzat yaşanmakta olduğu gözlemiyle başlar. Köktencilerin, İsrail ve diasporadaki nüfus içerisinde büyük bir orana sahip olmamakla birlikte, nüfuslarının çok ötesinde siyasi bir nüfuza sahip oldukları belirtilir. İsrail toplumunu İsrail A ve İsrail B olarak iki farklı kampa ayrıldığını, (A) kampının daha ziyade sol kanat, (B) kampının ise 'sağcı ve dinci' partilerin oluşturduğu sağ grubu temsil ettiğini savunan yazarlar, köktenciliğin egemen olduğu (B) kampının hızla genişlediği ve toplumun vakit geçtikçe sağa kaymakta olduğu tespitini yapar. Araştırmalar, İsrail Yahudilerinin \% 25-30'unun seküler, \% 50-55'inin geleneksel, kalan \% 20'lik oranın ise tamamen (köktenci) dindar olduğunu göstermektedir.

İsrailli dindar Yahudiler, belirgin olarak iki farklı gruba ayrılmaktadır. En aşırı uçtaki dindar grubun üyeleri "Haredim" olarak isimlendirilir. Dindarların içindeki daha 1lımlı grubun üyeleri ise dindar-milliyetçi Yahudiler olarak nitelendirilir. Bu dindar milliyetçiler, başlarını örttükleri için "örülü takke" olarak da isimlendirilirler ve dış görünüş açısından modernite ile uzlaşmış görünürler. Haredim kısmına dâhil olanlar, genellikle örülmüş olmayan siyah takke ya da şapka ve ağır paltolar giyerler. Diğer yandan, dindar-milliyetçi Yahudiler sıradan İsrail giysileri giyerken, Haredimler genellikle 1850'lerin Avrupa'sında yaşarken yaptıkları gibi, 
siyah elbiseler giyer. Kadınların sosyal hayattaki konumu Haredimler açısından tabu olup, kadın sesi dinlemeyi zina olarak görür, TV izlemek gibi sıradan davranışlardan kaçınırlar; dindar milliyetçiler içinse bu konular tabu değildir. Shahak, Haredimlerin toplum ve siyasetle olan ilişkileri ve din adamlarına aşırı rağbetini, İran'daki muhafazakârlara benzetir.

Yazarlar, sınırlı nüfusuna rağmen köktenci Haredimlerin siyasi sahnede güçlü olmaları ve isteklerini topluma dayatabilmelerini, merkez sol (İşçi) ve merkez să̆ (Likud) partileri arasındaki politik dengede bu grubun belirleyici olmasına, ayrıca sağcı Likud'un köktencilere sıcak ve yakın durmasına bağlar. "Dindar Yahudiler için, Yahudi olmayanların kanı aslında hiçbir değer taşımaz. Likud Partisi için ise, ufak bir değer taşır” tespiti bu yakınlığın göstergesi. Keza, diğer seküler İsraillilerden çok daha fazla oranda, İsrail sağının üyeleri, 'Yahudilerin eşsizliği' ve çok daha geniş bir İsrail fikrini savunur, her iki yaklaşım da köktendinci karakter taşır. Sağın her tonuna hâkim olan bu kafa yapısı, 'düşmandan sürekli korkma' ve 'kendine aşırı güven' sarmalında sürüp gider. Korku olgusu sadece dış düşmanla sınırlı değil, Batı kamuoyları ve Yahudi solcu-entelektüeller de korku duyulan kesimler arasında. Keza sol kanat, normalleşmeyi ve Yahudilerin de diğer halklar gibi 'normal' bir halk olmasını savunurken, 'Yahudi eşsizliğine' iman eden sağcılar için bu bir tabudur. Araplara kötü muamele ve işgal-yerleşimler konusunu, sağcılar “Tanrının seçilmiş halkı' oldukları faraziyesiyle açıklarken, sol kanat içinde bu görüşe meyilli olanlar zaman zaman sağ partilere bu konuda verilen tavizlerin sorumlusu olarak gösterilir. Ancak neticede, İsrail dış politikası her ne kadar seküler Yahudiler tarafindan planlanıyor ve uygulanıyorsa da, uygulamada Yahudi dininin geçmişinden alınmış bir öz taşımaktadır. Gerçekten de, kısmi bir laikleşmeye uğrayan Siyonist hareket dahi, temel Yahudi dini prensiplerini hala muhafaza etmektedir.

Haredimlerin, bir 'İsrail Devleti' kurulması ve dünyadaki tüm Yahudilerin buraya toplanması görüşüne ve dolayısıyla Siyonizme muhalefeti de bu bölümde ele alınır. Talmud' da yer alan, “1) Yahudiler, Yahudi olmayan kişilere karşı isyan etmemeli, 2) Mesih gelmeden önce Filistin'e toplu halde göç edilmemeli" kurallarının Siyonist ideallerle açıkça çeliştiğini; Filistin'e toplu Yahudi göçünün, tüm dünya milletleri buna razı olsalar dahi, beklenen Mesih'ten önce kesinlikle yasak olduğunu ifade ederler. Ancak köktenci Yahudiler arasında, Yahudilerin hâlihazırda, normal bir dönemde mi yoksa kurtuluş sürecinin başladığı dönemde mi bulundukları konusunda düğümlenen tartışmalar, Talmud'daki bu hükümlerin sadece 'zamanlaması' konusunda farklı yorumlar ortaya çıkarmaktadır. 
“Ísrail'de Haredim'in Yükselişi” başlıklı İkinci Bölüm, Yahudi köktenciliği her ne kadar 1970'1i yılların başlarında istikrarlı bir genişleme yaşadıysa da, seküler eğilimlerin ağır bastığı İsrail toplumunda 1988 yılına kadar göreceli olarak çok az ilgi görebildiği, Haredilerin şehirlerden ayrı alanlarda kendi halindeki yerleşim birimlerinde yaşadıkları tespitiyle başlar ve bu topluluğun seçimlerdeki başarıları ve \% 10'u geçen oy oranlarıyla, toplumun geneline kendi görüşlerini dayatabilmelerini sağlayan siyasi etkinliklerine odaklanır. Yazarlara göre bu sorunun cevabı, Haredilerin okullaşma ve eğitime olan aşırı ilgisinde aranmalıdır. Shahak, köktencilerin dini okullarındaki sıkı eğitim tarzını ve bu sistemdeki din adamı ve öğrencilerin çeşitli mükellefiyetlerden muaf tutulmasının toplumda doğurduğu rahatsızlığ 1 ve bu kesimin toplumu 'Tanrı ile aldatma' çabalarını uzun uzun örneklerle anlatır. Bu meyanda, örneğin, "Harediler, İsrail ordusunun almış olduğu tüm zafer ya da yenilgilerin Tanrı'nın dileğiyle olduğuna ve Tanrı'nın bu kararı verirken de, Talmud çalışmaları ile meşgul olan Yahudilerin sayısını, çalışma sürecini ve davranışlarını dikkate aldığına inanmaktadırlar” tespiti, sadece Yahudilere özgü olmasa gerek.

Shahak köktencilerin siyaset ve toplum üzerindeki kısıtlamalarının, örneğin Eğitim Bakanının bir Arap lokantasında yemek yerken görülmesi üzerine, koşer kurallarını ihlal ettiği iddiasıyla medyada linç edilmesinden yola çıkarak; Haredilerin İsrail demokrasisini tehdit ettiğini ve Lübnan-İran'daki Şii ulema gibi bir role bürünmeye hevesli oldukları yorumunu yapar. Aynı kadın bakanın, radikallerin eğitim kurumlarına en fazla kamu desteği aktaran bakan haline gelmesi de bu tür bir sosyo-politik iklim açısından şaşırtıcı değildir. Keza, "Tanrı'nın siyasal otoritesi resmi ve hukuki olarak tanınmalıdır. Yasama yetkisi, Tanrı'dan onaylı atanmış hahamlara verilmeli" talebinin, Şiilikteki velâyet-i fakih sistemiyle olan benzerliği dikkat çekici. Bu bölümde, kadınlara yönelik ayrımcı/dışlayıcı Haredi söylem-eylemleriyle ilgili çok sayıda çarpıcı örnek olay görmek mümkün. "Dindar bir Yahudinin, Yahudi olmayanlardan ya da din kurallarına uymayan diğer Yahudilerden nakledilen bir kanı alması caiz midir?" sorusu İsrail toplumunda geniş ölçekte tartış1lan ilginç konulara örnek olarak verilir.

“İki Haredi Grup: Sefaradlar ve Aşkenazlar” başlıklı Üçüncü Bölüm, Avrupa'daki iki temel Yahudi cemaati arasındaki farklılıklara odaklanır. Bu bağlamda Aşkenazların kendilerini daha dindar gördüklerini, Sefaradların ise kendilerinin daha 'saf ve üstün 1rk' olduklarına inandıklarını; her ki cemaatin bu yönlerden yekdiğerini küçümsediğini belirtir. Bunun sonucunda, Osmanlı Yahudileri, ülkeye göç eden Sefaradlardan etkilenerek, öyle olmadıkları halde kendilerini Sefarad olarak isimlendirmiş ve onların dili olan Ladino’yu öğrenmişlerdi. 
İsrail'e göç edenlerin yarısından fazlası Aşkenazi kökenli olup, gelişmiş ülkelerden geldikleri için daha modern ve laik görünüme sahiptiler. Sefarad Yahudileri ise geleneksel değerlere ve dindarlığa daha meyilli bir topluluk olarak kaldılar. Ancak Harediler çoğunlukla Aşkenazi olduğu için, köktenci hareket içinde Sefarad ağırlığı sınırı kaldı.

"İsrail' de çok iyi bilinen şey; farklı Yahudi dini gruplarının birbirine karşı beslediği nefretin yoğunluğunun, rakip laik partilerin birbirine beslediklerinden çok daha fazla olduğudur" tespiti, Sefarad-Aşkenaz kökenine göre dağılan Haredi siyasilerin birbirleriyle ilişkilerine dair ilginç bir detaydır. Bir süre sonra, köktenci partiler ruhani otorite konusunda aralarında anlaşamayarak bölündü, bu fraksiyonlar her vesileyle birbiriyle rekabete girmekten çekinmez.

“Ulusal Dini Parti $(N R P)^{i}$ ve Dindar Yahudi Yerleşimciler” başlıklı Dördüncü Bölüm, prestijli haham Rabbi Abraham Yitzhak Kook ve oğlu Tzvi Kook’un manevi önderliklerinde kurulan ve Filistin topraklarındaki yerleşimcilerden oluşan Gush Emunim (İnanç Bloğu) tarikatını ele alıp inceler. Batı Şeria ve Gazze'de hızla yayılan hukuksuz yerleşimler, bu tarikatın İsrail iç ve dış politikası üzerindeki etkisine bağlanmaktadır. Gush Emunim hahamları, 1980'lerin ortasında Ulusal Dini Parti (NRP - günümüzde Yahudi Yurdu Partisi) kadrolarını ele geçirip, partiyi tamamen kendi kontrolleri altına aldılar. Bu tarikat çoğunlukla, Ariel Şaron ve Benjamin Netanyahu gibi yerleşimlere destek veren sağ liderleri destekledi ve Filistinlilerle ilişkilerde en radikal şahin kanadı temsil etti. El-Halil'deki Hz. İbrahim Camii'nde Filistinlilere yönelik kitlesel katliam yapan Baruch Goldstein da, bu gruptandır. Shahak, tarikatın Mesiyanik zihinsel yapısı ve dünya görüşünü anlatan metinlerin analizini yaparken, Nazilerin ırkçı görüşleriyle bu yapınınkiler arasında çok fazla benzerlikler olduğuna işaret eder ve bunları örnekleriyle anlatır.

Yazarlar, bu bölümde köktenci Yahudilerin Filistin toprakları üzerinde yerleşimler kurarken yaslandıkları zihinsel arka planın, Talmud'daki 'Yahudi ırkı dışındakilerin insan bile sayılmayacakları' yönündeki ifade olduğunu yazar ve İbranice dışında yazılan metinlerde bu ifadenin kasten sansürlenip, gözden kaybedildiğini belirtir. Bu hastalıklı zihnin ürünü olarak, yeni yerleşim birimleri inşa etmek üzere el konulan Arap topraklarının, gerçekte bir çalma işi olmadığını, bilakis oralara kutsallık kazandırdığını öne sürerler. Onlara göre, topraklar şeytani olandan kutsal olana geçmekle aslında kurtulmaktadır. Rabbi Kook, her bir Yahudi'nin savaşla yükümlü olduğu ve savaş sanatını öğrenmek zorunda bulunduğu konusunda 1srarlıdır. Gush Emunim hahamları, Arapları katletmiş olan Yahudilerin kesinlikle 
cezalandırılmamaları gerektiğini sürekli yineler. Bu tarikat mensupları, İsrail'e "Tanrı'nın tahtının dünyevi dayanağı" yakıştırmasında bulunurlar. Shahak bu noktada kendini tutamaz ve "Böyle bir kutsallık anlayışının, bu dünyadaki Şeytan'ın gücünü sona erdirmek ve "Tanrı'nın yeryüzü saltanatını kurmak" için günün birinde nükleer bombaları patlatmaya yol açması hiç de olmayacak bir ihtimal değil" yorumunda bulunur.

Yazarlar, Gush Emunim'in İsrail Devleti için geliştirmiş olduğu dış politikanın, hükümetler tarafından benimsenmiş olduğunu ifade eder. Bu politika, Arapların Yahudilere olan düşmanlığının dini bir mahiyet arz ettiğini ve kalıtımsal olduğunu kabul etmektedir. Bundan çıkan sonuç da doğal olarak, Arap-İsrail ihtilafının kesinlikle siyasal yollarla çözümlenemeyeceği şeklinde olmaktadır. Tarikatın bir yayın organında yer alan şu ifade bakış açılarını özetlemektedir: “Onlar (seküler İsrail Hükümetleri) sadece, "İsrail'in tam ortasında hiçbir Yahudi'nin bulunmadığ bir Filistin devleti kurulmasını" istememişler, aynı zamanda, Yahudi İsrail devleti yerine laik ve demokratik bir ülke istemişlerdi. Bu hükümet, manevi olarak kokuşmuştur." Bölümün sonunda Haredi fanatiklerle Gush Emunim arasında bir mukayese yapan yazarlar, Gush Emunim ve NRP'nin daha büyük bir tehlike potansiyeli taşıdıklarını, zira bu gruplara mensup kişilerin, İsrail'i kutsamak üzere kendilerini devletin bünyesine entegre ettiklerini vurgular.

“Köktenci Gush Emunim Grubunun Yapısı” başlıklı Beșinci Bölüm, Batı Şeria ve Gazze'deki hukuksuz yerleşimlerdeki bu dindar yerleşimcilerin üç açıdan değerlendirilmesi gerektiğini savunur: i) Mesiyanik ideolojinin sığınağı olma konumları, ii) İsrail toplumu üzerinde hâlihazırdaki mevcut bulunan ve geleceğe yönelik potansiyel olarak var olan etkileri, iii) ruhani liderlerin inşa etmeye çalıştığı yeni toplumun ilk nüvesi olma rolleri. Sözkonusu yerleşimciler, büyük ölçüde Mesiyanik dünya görüşüne sahiptir, bu denli tehlikeli bölgelerde yaşamaları da dinlerinin bunu emrettiklerine inanmalarından kaynaklanıyor. Nitekim, İsrail'in, FKÖ ile anlaşma yapmakla manevi anlamda döneklik suçu işlediğini düşünecek kadar fanatik olabilmekteler.

Bu bölümdeki çarpıcı bir tespit İsrail siyasetinin doğasına vurgu yapmaktadır: "İki yüzlülük konusunda farklı derecelerde olmalarına rağmen 1967 yılından beri İşçi Partisi ile Likud Partisi tarafindan benimsenen temel anlayış, Filistinlileri maksimum etkili biçimde ezmek olagelmiştir. " İşçi Partisi taraftarlarının yanı sıra, siyasal sağ kanadın büyük bir bölümü, işgal altındaki topraklarda Filistinlilerin göreceli olarak sinmiş psikolojide tutulmaları için Gush 
Emunim' e sempatiyle bakmışlardır. Shahak, 1990’lı yıllarda barışın mimarları olarak takdim edilen Rabin-Peres ikilisinin esasen, takip ettikleri yerleşim politikalarıyla barışın önünde engel olduğunu savunur.

Çoğu Gush Emunim üyesi ve diğer köktenci gruplar, İsrail'in seçkin birliklerinde subaylık yapmaktadır ve bu tür birliklerde/askeri okullardaki oranları her geçen gün artmaktadır. $\mathrm{Bu}$ eğilime ilaveten, İsrail toplumunda, seküler ve sol görüşlü gençlerin güvenlik organlarında görev alma hevesi düştükçe, ordudaki dindarların oranı da artmaktadır. Ordunun üst düzey komuta kademesindeki subaylar, Filistinlilere karşı daha eziyet verici olmak istediklerinde, çoğunlukla dindar askerlere güvenmekte ve onları bu işler için kullanmaktadır. Ancak bilhassa Rabin suikastından sonra, ordu içindeki bu örgütlü yapılanmanın ve 'sızmanın', ortauzun vadede İsrail rejimi aleyhine olacağını düşünenlerin sayısı da az değil. Köktenci bir gazetede yayınlanan bir makalede serdedilen, “ilk yapmamı gereken, anayasa mahkemesini ele geçirmek, ardından genelkurmayı" ifadesi bu sızma girişimlerinin nihai hedefi konusunda da fikir vermektedir.

“Baruch Goldstein Olayının Gerçek Anlamı” başlıklı Altıncı Bölüm'de, Şubat 1994'te elHalil'deki Hz. İbrahim Camii'nde namaz kılmakta olan cemaatin üzerine ateş açarak 29 Filistinliyi katleden, birçoğunun da yaralanmasına yol açan fanatik dindar yerleşimci Baruch Goldstein'ın profili üzerinden, köktencilerin devletle olan ilişkileri ele alınıyor. Orduda hekim olarak görev yapan Goldstein, görev süresi boyunca pek çok kez Yahudi olmayan (çoğu Arap) yaralıları tedavi etmeyi reddetmiş, bu durumu bilinmesine rağmen ne cezalandırılmış ne de amirlerinden herhangi bir olumsuz tutuma maruz kalmış. Sonu katliama kadar giden süreçte, ordu içindeki bir el tarafından her defasında korunmuş. Goldstein'ın yaptıklarından, İsrail medyasında 'cinayet, katliam' vb kelimelerle değil de, 'hadise, eylem' gibi kavramlarla bahsedilmesi, adıgeçenin akıl sağlığının yerinde olmadığı söylenerek devlet tarafından korumaya alınması, fanatik bir kanaat önderinin 'Arapların ölümüne değil de oradaki sineklerin ölmesine üzüldüm' diyebilmesi, katliam günü kendisi de öldürülünce Cumhurbaşkanlığı tarafından şaşaalı bir resmi törenle gömülmesi, ardından yerleşimci fanatiklerin 'Goldstein İsrail'in hastalıklarını tedavi etti' yazılı rozetler takabilmesi, mezarının kutsal bir türbe haline getirilmesi gibi hususlar, devlet ve kamuoyunun katliama tepkisi açısından ibret vericidir. İsrail kamuoyu sağ ve sol kanadıyla, küçük ve çekingen bir kesim dışında, katliamı coşkulu bir şekilde karşıladı. Yazarlar, bu fanatik eylem kınansaydı, aynı çevrelerin bir süre sonra Başbakan Rabin'i suikastla öldürmeye teşebbüs edemeyeceği kanaatindedir. 
"Rabin Suikastının Dini Arka Planı" başlıklı Yedinci Bölüm, (nispeten) seküler-sol görüşleriyle bilinen İşçi Partili Başbakan Rabin'in öldürülmesinin ardından, dindar çevrelerin suikastı sahiplenmesi ve bunun dinin emri olduğunu söylemesi ve İsrail toplumunun suikast üzerinden kutuplaşmasını ele alarak, katliamın ardındaki dini ve tarihsel saikleri inceler. Bunu yaparken, başta Talmud, Ortaçă̆’’n en önemli Yahudi din adamı Maimonides ve diğer rabbilerin eserlerinden örneklerle, Yahudilikteki rutin şiddet geleneği ele alınır. Yazarlar, bu dindar fanatik terörizmin kökenlerinin Yahudi tarihinde bulunduğunu, MS. 66-73 tarihlerinde Romalılara karşı çıkarılan büyük isyanın ardından, meşhur Masada Kalesi'ne kaçıp sığınan Sikarikin grubunun Romalılardan değil, olaylar sırasında haydutluk edip saldırdıkları kendi dindaşlarından kaçtıklarını ve günümüzün fanatik teröristlerinin öncülleri olduğunu, aradan geçen uzun asırlar içinde kavram ve kişiliklerin birbirine karıştığını kaydeder. Rabin'in katili Yigal Amir; uzun tarihi dönem boyunca hahamlar tarafından işlenen şiddet eylemlerinin Tanrı'nın emirlerine uygun olduğu inancının öğrencilerin zihinlerine doldurulduğu yeshiva okullarında okumuş biridir.

Hıristiyan fanatizminden zarar gören Aşkenazların, İberya'da Müslümanlarla birlikte yaşayan Sefaradlara nazaran şiddete daha meyilli oldukları; İspanya gibi cemaatin nispeten özerk koşullarda yaşadığı ülkelerdeki Yahudi din adamlarının cemaat üzerinde dini hadleri tatbik etmekte daha serbest oldukları, ancak ABD’ye göç ederken Yahudilerin bu şiddet kültürünü yeni kıtaya götürmemeyi ve bundan hiç bahsetmemeyi tercih ettikleri; Yahudi cemaatlerinin kendi içlerinde aydın ve yenilikçi kişileri çoğunlukla din adamları eliyle aforoz veya linç etmeyi tercih etmeleri, en iyi ihtimalle topluluktan dışlamaları da bu bölümdeki önemli tarihsel tespitler arasında yer alıyor. Tarihsel metinlere göre, tüm bu süreçlerde 'Talmud'un kanının dökülmesine izin verdiği günahkâr olmak' lafzı, anahtar ifade şeklinde ön plana çıkmakta ve Yahudi tarihinde Rabin gibi önderlerin din adına öldürülmesine benzeyen çok sayıda örneğe rastlanmaktadır. Çeşitli dinci çevreler, Rabin ile Filistin otoritesi arasındaki gelişen ilişkileri Yahudi yerleşimcilere zarar verecek bir gelişme olarak yorumlayıp, Talmud'un bu hükmüne (bilhassa Yahudiler aleyhine muhbirlik yapanın öldürülmesi hükmü) açıkça atıfta bulunmuşlardı.

Yazarların, Yahudiliğe hâkim olan esas güdünün din ve milliyetçiliğin tehlikeli bir karışımı halindeki şovenizm olduğu, demokrasi ve hukuk gibi kavramların Yahudiliğe modern ulus devletler döneminde girdiği, bundan önceki döneme hâkim olan skolastik hahamların 
idaresindeki cemaat yapısına dönmeyi hâlihazırda içtenlikle arzulayan çok geniş bir kitle olduğuna dair tespitleri ise mevcut durumun vahametini ortaya koymaktadır. Keza, Yahudi şeriatında yer alan ve halen daha belirli çevrelerde uygulanan sert ve ölümcül cezaların, İsrail dışında kamuoyunda bilinmemesi ve İngilizce yayınlarda bu hususların yer almaması için ciddi gayret gösterildiği; buna mukabil İran, Taliban veya diğer köktenci rejimlerdeki benzer uygulamalar konusundaki hassasiyetin İsrail sözkonusu olunca göz ardı edildiği tespiti yapılmaktadır. Kitabın son paragrafındaki, "Yahudi köktencilerin, kendi aralarından çıkmış olan sapkınlara karşı tutumu, Yahudi olmayanlara karşı davranışlarından daha kötüdür. Ĕ̆er İsrail'de köktenci bir Yahudi rejimi iktidara gelirse, bu iktidarın, kendi ilkelerini kabul etmeyen İsrail Yahudilerine yönelik tehdidi Filistinlilere yönelik tehdidinden çok daha kötü olacaktır. İşte bu kitap, Yahudi köktenciliğinin daha geniş çerçevede anlaşılmasını sağlama girişiminden başka bir şey değildir ve gerçekleşmekte olan bir tehlikeyi önlemede yardımcı olması umulmaktadır" ifadesi ise alarm zillerini çaldıracak derecede kaygı vericidir.

Kitabın sonunda, Israel Shahak, çeşitli örnekler getirerek, tarihsel süreç içerisinde Yahudi dininin aslında tek Tanrıcı karakterde olup olmadığı sorusuna kısaca değinmekte ve Türkçeye de çevrilen Jewish History, Jewish Religion başlıklı kitabında ${ }^{2}$ bu konuyu işlediğini belirtmektedir. $\mathrm{Bu}$ kitabın ardından, kuşkusuz bu kışkırtıcı konuyu tetkik etmek için, Shahak'ın diğer çalışmasına da göz atmak faydalı olacaktır.

\section{b). 2021 Mart Knesset Seçimleri ve Yahudi Fundamentalizminin İsrail İç Siyasetindeki} Rolü

Shahak \& Mezvinsky'nin kitabında ele alınan radikal/köktenci Yahudilerin İsrail iç siyasetindeki rolüne bakmak açısından; 2021 Ramazan ayında [Nisan-Mayıs] Kudüs’teki Araplara ait kadim Şeyh Cerrah mahallesinde, Yahudilerin devlet tarafindan da müsamaha gören provokasyonuyla başlayan ve Gazze’yle Batı Şeria’ya, hatta İsrail içindeki Araplara da sıçrayan karışıklıklar ve başkaldırı süreci önemli bir örneklik sunmaktadır. Bu olayların da gösterdiği somut gerçeklik; köktenci Yahudilerin bilhassa yerleşimler ve yerleşimciler üzerinden, İsrail siyasetini domine etmeye devam ettiği, sol siyasetin zayıfladığ mevcut denklemde, sağ siyasetin bu radikal unsurları "sırtında taşımaya" politik saiklerle mecbur olduğudur. Nitekim uzun müzakerelerin ardından, 2021 Haziran ayı sonu itibariyle ancak

\footnotetext{
${ }^{2}$ Israel Shahak, Yahudi Dini Yahudi Tarihi, trc. Ahmet Emin Dağ, (İstanbul: Ağaç Kitabevi, 2010)
} 
kurulabilen hükümet müzakerelerindeki denklemler de săg partiler - köktenci radikaller işbirliğinin devamına işaret etmektedir.

İsrail'deki siyasi partiler ve Meclis aritmetiğinin (toplam 120 sandalye) son genel seçimler (23 Mart 2021) çerçevesinde güncel dağılımı şu şekildedir [Meclis'e girmek için gerekli baraj olan $\% 3,25$ oy oranını 13 parti geçebildi]:

\begin{tabular}{|c|c|c|c|}
\hline Parti adı & $\begin{array}{l}\text { Oy } \\
\text { oranı } \\
(\%)\end{array}$ & $\begin{array}{l}\text { Sandalye } \\
\text { sayısı }\end{array}$ & Açıklama \\
\hline LiKUD & 24,19 & 30 & $\begin{array}{l}\text { Başbakan Binyamin Netanyahu } \\
\text { liderliğindeki milliyetçi eğilimli, merkez } \\
\text { sağ parti }\end{array}$ \\
\hline YEŞ ATID & 13,93 & 17 & $\begin{array}{l}\text { Eski gazeteci Yair Lapid'in, seküler orta } \\
\text { sinifları temsil eden partisi }\end{array}$ \\
\hline *ŞAS & 7,17 & 9 & $\begin{array}{l}\text { 1984'te kurulan ve Rabbi Ovadia Josef' in } \\
\text { ruhani liderliği altındaki, Sefarad/Mizrahi } \\
\text { ultra-Ortodoks (Haredi) parti }\end{array}$ \\
\hline MAVİ BEYAZ & 6,63 & 8 & $\begin{array}{l}\text { Benny Gantz liderliğindeki merkez parti } \\
\text { (eski merkez-liberal ittifakın bakiyesi) }\end{array}$ \\
\hline YAMINA & 6,21 & 7 & $\begin{array}{l}\text { Naftali Bennett'in liderliğindeki yeni-sağ } \\
\text { parti; eski Yahudi Yurdu Partisi'nden } \\
\text { kopanların kurduğu dindar-Siyonist yapı }\end{array}$ \\
\hline İşÇI PARTISİ & 6,09 & 7 & $\begin{array}{l}\text { Köktenci bir Yahudi’nin suikastle } \\
\text { öldürdüğü İzak Rabin'in, kan kaybı süren, } \\
\text { soldaki geleneksel partisi }\end{array}$ \\
\hline $\begin{array}{l}\text { *BİRLEŞİK TEVRAT } \\
\text { YAHUDİLİĠ }\end{array}$ & 5,63 & 7 & Aşkenaz ultra-Ortodoks (Haredi) parti \\
\hline İSRAİL EVİMİZ & 5,63 & 7 & $\begin{array}{l}\text { Temelde SSCB göçmenlerine dayanan, } \\
\text { eski Dışsisleri-Savunma Bakanı } \\
\text { Lieberman'ın seküler Siyonist-sağ partisi }\end{array}$ \\
\hline DİNI SIYONIZM PARTİSİ & 5,12 & 6 & $\begin{array}{l}\text { Bezalel Smotrich liderliğinde, ultra sağ } \\
\text { çizgideki dindar-milliyetçi parti }\end{array}$ \\
\hline MÜŞTEREK (ARAP) LİSTE & 4,82 & 6 & $\begin{array}{l}\text { Güç kaybı yaşayan, Eymen Avde (Ayman } \\
\text { Odeh) liderliğindeki; Hadass, Balad ve } \\
\text { Ta'al partilerinin oluşturdukları ortak } \\
\text { Arap listesi }\end{array}$ \\
\hline YENİ UMUT & 4,74 & 6 & $\begin{array}{l}\text { Likud'dan kısa süre önce ayrilan Gideon } \\
\text { Saar'ın liderliğindeki sağ parti }\end{array}$ \\
\hline MERETZ & 4,59 & 6 & $\begin{array}{l}\text { Nitzan Horowitz liderliğinde, sol-seküler } \\
\text { parti }\end{array}$ \\
\hline $\begin{array}{l}\text { BİRLEŞİK ARAP LİSTESİ } \\
\text { [RA'AM] }\end{array}$ & 3,79 & 4 & $\begin{array}{l}\text { Mansur Abbas'ın öncülük ettiği, ikinci } \\
\text { Arap siyasal grubu (İslamcı eğilimli) }\end{array}$ \\
\hline Toplam & & 120 & \\
\hline
\end{tabular}


Kaynak: The Twenty-Fourth Knesset Elections (March 23, 2021),

https://knesset.gov.il/description/eng/eng_mimshal_res24.htm. Partilere ilişkin değerlendirmeler yazara aittir.

Bu Meclis aritmetiği; bu kitapta sözü edilen köktenci Yahudi partilerin (Şas ve Birleşik Tevrat Yahudiliği) toplam $\% 12,8$ oy oranıyla ve 16 vekille Knesset'te temsil edildiğini göstermektedir. Kitapta referans alınan 1996 seçimlerinde, bu iki partinin 14 sandalyesi vardı; 2015 seçimlerinde ise \%10,73 oy oranı ve 13 vekile sahipti. Buna karşılık, bu kitleye yakın duran sağ ve Siyonist partiler ise toplam \%40 civarında oy oranına ve 49 sandalyeye sahiptir. Nitekim, aralarındaki kısmi görüş ayrılıklarına rağmen, son dönemdeki diğer hükümetler gibi, 12 yıllık Binyamin Netanyahu hükümeti de siyaseten ve kültürel açıdan birbirine yakın duran bu iki kesimin işbirliğiyle kurulmuştu.

2021 Haziran ayında, Netanyahu karşıtlı̆̆ında bir araya gelebilen sağ ve sol yelpazedeki çeşitli partiler, zor da olsa bir hükümet kurabildi ve parlamentodan güvenoyu alarak göreve başladı. Buna göre, Netanyahu'dan boşalacak başbakanlık koltuğunu iki yıllığına Yamina lideri Naftali Bennett elinde tutacak. Bennett, Ağustos 2023'te koltuğu koalisyon ortağ1 Gelecek Var (Yeş Atid) Partisi lideri Lapid'e devredecek. Her ne kadar Netanyahu ve aşırı sağdaki koalisyon ortakları bir blok halinde hükümet etmeyi sürdüremeyecek olsa ve Abbas'ın Birleşik Arap Listesi de koalisyon ortağı olsa da çeşitli soru işaretleri öne çıkmaktadır.

Toplam sekiz partiden oluşan ve 120 üyeli Knesset'te 60 üyenin oyuyla güvenoyunu son anda alabilen mevcut hükümet açısından, öncelikle Bennett'in aşırı sağa hitap eden şahin söylemlerinin yanısıra; Netanyahu'nun Likud'undan ayrılan Sarr'ın adalet bakanı, Netanyahu'nun eski ortağı İsrail Evimiz Partisi lideri Lieberman'ın maliye bakanı olacağı koalisyonda İsrailli Arapların listesinin de temsil edilmesi; bu kadar parçalı bir yapının ne kadar uzun süreli olabileceğinin sorgulanmasına yol açmaktadır. Tabiatıyla, bu parçalı yapının yola devam edememesi halinde, en güçlü alternatif yine Netanyahu önderliğinde 'sağ-dindar să̆' ittifakının İsrail'i yönetmesi olacaktır.

İsrail iç siyasetinin, bilhassa son otuz yıldaki kompozisyonu ve ülkenin varoluşsal ehemmiyet arzeden yerleşim / güvenlik politikaları göz önüne alındığında, mevcut politik ve toplumsal parametreler ekseninde; sağ siyasetin güçlenmeye devam edeceği, zayıflayan sol siyasetin zemin kaybının süreceği, özellikle yerleşimler ve toprak siyaseti üzerinden aşırı sağla iç içe 
geçen köktenci Yahudi partilerin zemin kazanmaya devam edeceği tahmine müsaittir. Son seçimde -uzun yıllardır uygulanan düşük seçim barajı sayesinde- 13 politik grubun temsil edildiği Knesset'in parçalı yapısı ve ülke iç siyasetinde birkaç milletvekilli grupların bile stratejik ehemmiyet arz etmesi gibi faktörler; sözkonusu gruplara ait Şas ve Birleşik Tevrat Yahudiliği gibi parti ve grupların, politik temsillerinin çok ötesinde nüfuz kazanabilmesine olanak sağlamaktadır. Öngörülebilir gelecekte de bu politik dengelerin mevcut haliyle devam etmesi en muhtemel senaryo olacaktır. 